University of Wyoming College of Law

Law Archive of Wyoming Scholarship

$1-30-2020$

\title{
All the World's a Platform?: Some Remarks on 'Marketplace Platform' Employment Laws
}

Michael C. Duff

University of Wyoming College of Law, michael.duff@slu.edu

Follow this and additional works at: https://scholarship.law.uwyo.edu/faculty_articles

\section{Recommended Citation}

Duff, Michael C., "All the World's a Platform?: Some Remarks on 'Marketplace Platform' Employment Laws" (2020). Faculty Articles. 75.

https://scholarship.law.uwyo.edu/faculty_articles/75

This Article is brought to you for free and open access by the UW College of Law Faculty Scholarship at Law Archive of Wyoming Scholarship. It has been accepted for inclusion in Faculty Articles by an authorized administrator of Law Archive of Wyoming Scholarship. 


\title{
All the World's a Platform?: Some Remarks on "Marketplace Platform" Employment Laws
}

\author{
By Michael C. Duff ${ }^{1}$
}

\section{I. $\quad \underline{\text { Introduction }}$}

This paper addresses the enactment of marketplace platform laws, which have arisen as a remarkable feature of the gig economy ${ }^{2}$ in recent years. A marketplace platform law decides the question of whether an individual worker is an independent contractor or an employee - an ongoing controversy in all employment law, including workers' compensation law — by emphasizing factors other than those normally considered in traditional legal analyses. ${ }^{3}$ As of this writing, seven states appear to have enacted marketplace platform laws. ${ }^{4}$ Before focusing on one such marketplace platform law, some context on any gig law discussion may be helpful.

Legal academics have noted that there are essentially two dominant currents of theoretical perspective on the gig economy writ large: it is seen either as an utter canard explained by the desire to evade existing law, or as an evolution of the very nature of work. ${ }^{5}$ It has been suggested that one way to break through this conceptual bifurcation may be to "effectively distinguish app employees from bona fide independent contractors ... [by] ask[ing] the same question that initially sparked the independent contractor designation: Do today's 'independent contractors' possess sufficient skill and economic autonomy to stand alone in the marketplace?"6 The problem with this perspective is that it is not at all clear that the original establishment of the independent contractor classification had anything much to do with imposing liability on those likely to be able to compensate injury victims. Rather, creation of the independent contractor category may simply have been a strategy allowing masters to escape tort liability created by putative servants. In other words, creating a category of "not servants" may have had more to do with a "push" policy of tortliability-avoidance than a "pull" policy of consciously-allocative tort compensation (leaving entirely to one side questions of employment law-including workers' compensation-coverage).

The distinction between a servant or employee and an independent contractor has been said to lie in the fact that the latter does the work on his own time, in his own way, and under no one's directions but his own, so that the one who selected the contractor has no control or right of control over the manner in which it is done. It is therefore to be regarded as the contractor's own enterprise, and he, rather than the one who retained his services, is the proper party to be charged with the risk. Also, no doubt, there is in the picture, although not often expressed, the fact that, taken as a class, independent contractors are in the main financially responsible parties, at least to a far greater extent than employees. ${ }^{7}$ (Emphasis supplied)

Thus, the foundation for the original independent contractor category was probably that the "master" ought not to be held accountable for circumstances over which he or she had no control, for reasons of fairness, and it was occasionally a happy fortuity that some entities deemed to be independent contractors turned out to be "financially responsible parties" (at least in comparison to penniless "employees"), though one may very much doubt that it was the primary reason behind 
the employee-independent contractor bifurcation. ${ }^{8}$ Moreover, the whole idea of vicarious liability (respondeat superior) was "bitterly" contested by common law judges throughout the $19^{\text {th }}$ century. ${ }^{9}$ The earliest English precedents fail to cite authority for the proposition that vicarious liability existed; and no less a luminary than Oliver Wendell Holmes thought the common law version was a fiction derived from Roman law: if my servant (a chattel) harmed you, you had the right to kill or maim my servant. ${ }^{10}$ To avoid this result, I could pay you compensation. Over time, some links in the chain were lost, and it became the rule that I could simply approach you (the master) for compensation for the wrongs done by your servant, though you were in no sense at fault. ${ }^{11}$ There seems no getting around the fact that respondeat superior was (and is) a form of strict liability, and that without the respondeat superior doctrine there would be no disputes over "independent contractors" in tort cases because masters would have no need to escape liability for the torts of their servants.

So much for a clean tort theory on the origins of the independent contractor doctrine being grounded somehow in the liability-worthiness of contractors. And if respondeat superior was a mere public policy expedient - the brute ability to recover from deep pockets - small wonder that disputes over whether a worker is truly a "servant" have been ongoing since the mid-nineteenth century. If you are going to arbitrarily fleece me under respondeat superior, regardless your good social intentions, I am going to resist. Nineteenth-century judges seemed extremely reluctant to hold the users of "workers" liable in all cases, and the instinct to prevent the perceived injustice of such strict liability seemed strong. ${ }^{12}$ Still, respondeat superior "won out," and there is probably more than one economic explanation for why it did. Perhaps an explanation hitting closer to the mark than the placement of liability on parties that could pay simply because they could pay (employees, no liability because unable to pay; independent contractors, liability, because able to pay), is that of the "cheapest cost avoider." Liability might simply be placed on the party having control of the risks inherent in activity because that party could take precautions against those risks. This idea provides a plausible explanation of why workers' compensation (and other employment) law has remained firmly connected to common law principles to notions of controlthe entity that controls workplace conditions may take precautions against various forms of "antisocial" conduct. It is also a public policy seeming to marry ideas of justice, general deterrence, and instrumental realism. ${ }^{13}$

\section{II. "Classical” Workers' Compensation}

Whatever the economic justifications for creation of independent contractor doctrine in the nineteenth century, and despite nineteenth-century judicial resistance to concepts of respondeat superior in tort contexts, the first English workers' compensation statute (of 1897) — which was the prototype for early American workers' compensation statutes-made no bones about significantly interfering with attempts by employers to unilaterally designate workers as independent contractors:

Where, in an employment to which this Act applies, the undertakers as herein-after defined contract with any person for the execution by or under such contractor of any work, and the undertakers would, if such work were executed by workmen immediately employed by them, be liable to pay compensation under this Act to those workmen in respect of any accident arising out of and in the course of their 
employment, the undertakers shall be liable to pay to any workman employed in the execution of the work any compensation which is payable to the workman (whether under this Act or in respect of personal negligence or wilful act independently of this Act) by such contractor, or would be so payable if such contractor were an employer to whom this Act applies.

Provided that the undertakers shall be entitled to be indemnified by any other person who would have been liable independently of this section.

This section shall not apply to any contract with any person for the execution by or under such contractor of any work which is merely ancillary or incidental to, and is no part of, or process in, the trade or business carried on by such undertakers respectively. ${ }^{14}$

Readers may recognize this language as a foundational form of "statutory employment."15 If an "undertaker" employed contractors to do work that was not merely "ancillary or incidental" to, and was a part of, or process in, the trade or business carried on by the undertaker, the contractors were covered "workmen" under the act. It is on this "part of, or process in" question that market contractor laws seem to depart significantly from workers' compensation theory.

\section{III. $\quad$ Platform Laws Meet the 1897 Test}

In 2018, a number of states passed "market contractor" laws under the apparent lobbying impetus of the company, Handy, Inc. ${ }^{16}$ As will be shown, these laws unquestionably make it significantly easier for companies to classify their workers as independent contractors rather than employees, thereby lowering their operating costs, but also creating a class of individuals with fewer legal protections when suffering on-the-job injuries. ${ }^{17}$ Although styled as laws applicable only to retired handymen, and similar part-time workers, the text of the laws is much broader than this innocuous characterization suggests. ${ }^{18}$ Simply put, they do not, by their terms, apply only to handymen (or similar categories of workers), nor do they apply only to part-time workers. But even the innocuous characterization of the laws might give one pause. In what sense are laws applicable to handymen touching on a revolutionary new economy (the apparent premise for why gig laws are justifiable in the first place)? These are very broad laws with no obvious, narrower connection to the "mysterious" world of high-tech coders, and the like, whose work, we are told, defies analysis under traditional restatement factors. What makes the employment seem "gig-like" to legislators appears to be that workers are dispatched to their work with an app, or even just through a computer. Almost identical laws were passed in in Arizona (2017), ${ }^{19}$ Florida, ${ }^{20}$ Indiana, ${ }^{21}$ Iowa, ${ }^{22}$ Kentucky, ${ }^{23}$ Tennessee, ${ }^{24}$ and Utah $(2018)^{25}$-not all of these are locations that might evoke images of a booming, high-tech economy. ${ }^{26}$ Handy-laws were defeated in Alabama, California, Colorado, and Georgia. ${ }^{27}$ This paper aims to briefly show how expansive these marketplace platform laws are by focusing closely on statutory language. The laws impact workers' compensation significantly because each of them carries the talismanic phrase that the law applies "for all purposes under state and local laws, rules, ordinances, and resolutions . .."28 The advocacy group National Domestic Workers' Alliance argued, in connection with enactment of a Handy law in Tennessee: 
The [Chattanooga] Times Free Press reported that sponsor Senator Watson likened "the marketplace platforms to business advertising in newspapers." We invite Senator Watson to talk to a Handy worker, who will explain that marketplace platforms set the rates of workers, charge workers fines for changing their work schedule, facilitate payments and change rates of workers according to reviews. Not much like a newspaper when you think about it, is it? $?^{29}$

Thus, the argument centers on a debate as to whether a "marketplace platform" is no more than a passive information clearinghouse merely offering "disinterested" space for contractors and third parties to enter into contractual relationships without the platform having any input into what happens thereafter. ${ }^{30}$ In other words, are marketplace platforms "undertakers" (to use the language from classical workers' compensation) contracting "with any person for the execution by or under such contractor of any work, and the undertakers would, if such work were executed by workmen immediately employed by them ..." or is the work of contractors "merely ancillary or incidental to, and is no part of, or process in, the trade or business carried on by such undertakers ..."

\section{Analysis of a Handy/Contractor Law-Tennessee}

Because the platform laws under discussion are nearly identical, analysis of just one of them, Tennessee's, will suit the purposes of this short paper:

Under the selected law, ${ }^{31}$ a "marketplace contractor" working for a "third party" at the direction of a "marketplace platform" is an independent contractor as a matter of law if:

(1) the platform and contractor agree in writing that the contractor is an independent contractor with respect to the market platform;

(2) the platform does not unilaterally prescribe specific hours of work. If a marketplace contractor posts the contractor's voluntary availability to provide services, the posting does not constitute a prescription of hours;

(3) the platform does not prohibit the contractor from using any online-enabled application, software, website, or system offered by other marketplace platforms;

(4) The marketplace contractor may, at its discretion, enlist the help of an assistant to complete the services, and the marketplace platform may require the assistant to complete the marketplace platform's standard registration and vetting process. If the marketplace contractor enlists the help of an assistant, the marketplace contractor, not the marketplace platform, is responsible for paying the assistant;

(5) The marketplace platform does not restrict the marketplace contractor from engaging in any other occupation or business;

(6) The marketplace platform does not require marketplace contractors to use specific supplies or equipment; 
(7) The marketplace platform does not control the means and methods for the services performed by a marketplace contractor by requiring the marketplace contractor to follow specified instructions governing how to perform the services. However, the marketplace platform may require that the quality of the services provided by the marketplace contractor meets specific standards and requirements;

(8) The agreement or contract between the marketplace contractor and the marketplace platform may be terminated by either the marketplace contractor or the marketplace platform with or without cause;

(9) The marketplace platform provides no medical or other insurance benefits to the marketplace contractor, and the marketplace contractor is responsible for paying taxes on all income derived as a result of services performed to third parties from the assignments or connections received from the marketplace platform; and

(10) All, or substantially all, payment to the marketplace contractor is based on performance of services to third parties who have engaged the services of the marketplace contractor through the marketplace platform.

Before setting out more of the law, it may be worth remarking here that factor seven (the statute, like the Restatement Second of Agency, utilizes ten factors) - control-would be extremely important in many employee-versus-independent contractor analyses. Indeed, under the $\mathrm{ABC}$ test that is at the heart of the AB 5/Dynamex rule in California, ${ }^{32}$ the burden would be on the putative employer to establish its absence of control, Under the Tennessee law, however, the control factor is merely one of ten, and the other nine seem designed to be very easy for a "market platform" to satisfy. For example, rather than determining whether a putative independent contractor in fact engages in another business or calling - as would be the question in a Restatement analysis, ${ }^{33}$ it is enough for the platform not to have restricted the worker from doing so. Similarly, the question under the Handy laws is whether the platform requires the contractor to use specific supplies or equipment or prevents the contractor from seeking other employment, not whether the contractor actually does so. ${ }^{34}$ Thus, in addition to providing a simplified factor test weighted in favor of finding an independent contractor status, the law also seems designed to disregard consideration of the economic realities surrounding the relationship between the contractors and the platform.

Continuing with exposition of the law, a "marketplace contractor" means ${ }^{35}$ any individual, corporation, partnership, sole proprietorship, or other business entity that:

- Enters into an agreement with a marketplace platform to use the platform's onlineenabled application, software, website, or system to be given an assignment, or otherwise receive connections, to third-party individuals or entities seeking its services in this state; and

- In return for compensation from the third-party or marketplace platform, offers or provides services to third-party individuals or entities upon being given an assignment or connection through the marketplace platform's online-enabled application, software, website, or system. 
A “marketplace platform," in turn 36 "means a corporation, partnership, sole proprietorship, or other business entity operating in this state that offers an online-enabled application, software, website, or system that enables the provision of services by marketplace contractors to thirdparty individuals or entities seeking the services." Under this definition it is difficult to conceive any company that could not characterize itself as a marketplace platform. Companies use "onlineenabled" websites, after all. Customers may be recast as "third-parties." When the customer contacts the company he or she is "seeking services" from service-provider-employees, now recast as "marketplace contractors" who, after all, "agreed" in advance and in writing that they were contractors. (Something that students of the history of workers' compensation may recognize as a thinly-disguised pre-injury waiver of liability).

Imagine a situation in which a contractor is subject to discipline if he or she does not comply with a work schedule "voluntarily" posted by the platform; imagine a contractor who does not in fact use other "platforms" but has used the same "platform" exclusively for a period of years; imagine a contractor who does not in fact engage in any other occupation or business than his or work through the platform (and never has); imagine a contractor who in fact uses platformprovided supplies or equipment (and always has); and imagine a platform that in fact supplies supervision to the contractor. None of this may matter for purposes of the independent contractor analysis if the worker has "agreed in writing" that he or she is not an employee, and if a company offers an "online-enabled application." Thus, if one calls the plumbing company this year (just as one called the plumbing company last year), the company might announce that it is not a plumbing company, after all, and that you are not a "customer" but rather a "third-party." The plumbing company has reimagined itself as a technology company because it possesses a website and dispatches to jobs its now-contractor-plumbers through use of a Google app and a couple of handfuls of Tracfones. If the benefit gained through such a metamorphosis is a complete release of the company from the obligation to comply with a state's labor and employment laws, none of this is at all difficult to imagine.

\section{Conclusion}

It is a simple axiom of workers' compensation policy that an industry must pay for the costs of its injuries. One can pretend that Handy is not in the industry of handymen or Uber is not in the industry of transportation. In a sense this is true in the way it is also true that no business is permanently tethered to its business. Apple (an actual technology company) happens to be in the business of providing technology because it is profitable. If it were not profitable, Apple would exit the business and invest its capital elsewhere. But while it is in the technology business, it is in technology business. Handy Inc. may only temporarily happen to be in the industry of providing handymen, but while it is providing Handymen, it is engaged in the industry of handymen. It seems very bad policy to exempt companies within an industry from sharing the burden of the costs of injuries to its "workers" without fully exploring the relationship between the platform and those workers.

It has always been fundamental to workers' compensation that workers engaged in the process of a venturer's business may be treated as employees if the business would otherwise have used "employees" to carry on its core activities (the "B" factor in the ABC test). In the language of the "old" workers" compensation law, workers should be covered if they are part of the trade or business carried on by the "undertakers" of productive activity. A society might come to a different 
conclusion about how to allocate the costs of injury (or how to disseminate other social polices embedded in employment statutes) than to cover "employees" by industry sectors. But changing the rules for coverage - or effectively discontinuing coverage altogether-should be carefully discussed and deliberated upon by the broader society. Regrettably, platform workers, including handymen, will be injured in the course of work. Who will pay for the costs of injury, and how much will be paid? These questions have historically been decided transparently by the body politic; and experience counsels the use of democratic process before embarking on a public policy adventure.

Market platform laws also aggravate the growing disuniformity in "employment status" determinations throughout the United States. To the ABC and Restatement tests is now added the seven-state marketplace platform test. One may recall that a central justification for enactment of the federal employment benefit statute, the Employee Retirement Income Security Act of 1974 (ERISA), was to relieve employers from the burdens of having to comply with different benefit structures throughout the country. "Requiring ERISA administrators to master the relevant laws of 50 States and to contend with litigation would undermine the congressional goal of 'minimiz[ing] the administrative and financial burden[s]' on plan administrators - burdens ultimately borne by the beneficiaries." 37 Even within states employee definitions can differ between employment statutes. ${ }^{38}$ Now it appears we may have national "zones" in which employee determinations may significantly (or even completely) differ: ABC, Restatement/Common law, marketplace platforms. ${ }^{39}$ In the din arising from this disuniformity, the policy of adequate compensation for workplace injury often seems lost.

\footnotetext{
${ }^{1}$ Professor of Law, University of Wyoming College of Law.

2 "[E]conomic activity that involves the use of temporary or freelance workers to perform jobs typically in the service sector." MERRIAM-WEBSTER available at https://www.merriam-webster.com/dictionary/gig\%20economy

${ }^{3}$ See e.g. Tennessee's version at T. C. A. § 50-8-101-103 (2019). Most legal analyses emphasize whether the employer or the worker have "control" in the workplace, though other factors are considered as well. See Restatement Second Section 220(2) of Agency and Restatement Third of Agency Section 7.07(f). The "ABC" test, in use in several states, also analyzes control, along with other factors, but places the burden on the putative employer, rather than the putative employee, to show that it lacks control of the details of the employee's work. The recently-codified version of the California version of the $\mathrm{ABC}$ test (but note, not applicable to workers' compensation cases) states that "a person providing labor or services for remuneration shall be considered an employee rather than an independent contractor unless the hiring entity demonstrates that the person is free from the control and direction of the hiring entity in connection with the performance of the work, the person performs work that is outside the usual course of the hiring entity's business, and the person is customarily engaged in an independently established trade, occupation, or business. California Labor Code, 2750.3. (Emphases supplied).

${ }^{4}$ See infra. at notes 19-25 and accompanying text.

${ }^{5}$ Keith Cunningham-Parmeter, Gig-Dependence: Finding the Real Independent Contractors of Platform Work, 39 NORTHERN ILL. L. REV. 379, 381-82 (2019)

${ }^{6} I d$. at 383

${ }^{7}$ Prosser, Wade, AND Schwartz, TorTs: CASES AND MATERIALS 697, n.1 (12 $2^{\text {th }}$ Edition)

${ }^{8}$ Charles Pierson, A Recent Attempt to Limit the Independent Contractor Doctrine, 8 YALE L. J. 63 , 64 (1898) (noting that the theoretical justification for respondeat superior was weak and "[a] sense of its harshness and a desire to restrict its operation are no doubt partly responsible for the evolution of the Independent Contractor Doctrine").

${ }^{9}$ DAVID G. HANES, THE FIRST BRITISH WORKMEN's COMPENSATION ACT, 1897 (Yale University Press 1968)

${ }^{10} I d$. at $9-10$

${ }^{11} I d$.

${ }^{12}$ See e.g. Blake v. Ferris, 5 N.Y. 48 (1851) (upholding a challenge to the trial court's refusal to instruct the jury that the "employer" could not be held liable for the acts of its independent contractor).
} 
${ }^{13}$ But see Guido Calabrese, Does the Fault System Optimally Control Primary Accident Costs, 33 LAW \& CONTEMP. PROBS. 430, 441 (1968) (explaining asymmetrical operation of the cheapest cost avoider principle in workers' compensation contexts)

${ }^{14}$ English Workers' Compensation Act of 1897, Chapter 37, 60 \& 61 Vict., Section 4

${ }^{15}$ For a modern discussion of these issues see 4 LARSON's WORKERS' COMPENSATION LAW $§ 70$

${ }^{16}$ Sarah Kessler, "Handy is Quietly Lobbying State Lawmakers to Declare its Workers Aren't Employees," Quartz at Work, Mar 30, 2018, https://work.qz.com/1240997/handy-is-trying-to-change-labor-law-in-eight-states/ .

${ }^{17}$ Rebecca Smith, 'Marketplace Platforms' And 'Employers' Under State Law-Why We Should Reject Corporate Solutions And Support Worker-Led Innovation, National Employment Law Project (2018) available at https://www.nelp.org/publication/marketplace-platforms-employers-state-law-reject-corporate-solutions-supportworker-led-innovation/\#_edn14

${ }^{18} I d$.

${ }^{19}$ Arizona Revised Statutes Title 23-1603

${ }^{20}$ Florida Statutes Chapter 451 (passed allegedly after a mere ten minutes of discussion, https://www.tampabay.com/florida-politics/buzz/2018/03/12/florida-lawmakers-approve-last-minute-change-onbehalf-of-powerful-lobbyist/)

${ }^{21}$ Indiana Statutes § 22-1-6-3

${ }^{22}$ Iowa Code Ann. $§ 93$

${ }^{23}$ Kentucky Revised Statutes $§ 336.137$

${ }^{24}$ Tennessee Code Annotated § 50-8-101

${ }^{25}$ Utah Code Annotated $\S 34-53-102$ (appears limited to building services contexts)

${ }^{26}$ The Handy lobbyist is not exactly coy about strategy:

If starting with the harder states failed, we're taking a shot at something's that a little faster," said venture capitalist and political strategist Bradley Tusk, whose firm Tusk Ventures ran Uber's state legislative campaign and now represents Handy. "What is ultimately a better business decision? To try to change the law in a way that you think works for your platform, or to make sure your platform fits into the existing law? https://money.cnn.com/2018/03/14/news/economy/handy-gig-economyworkers/index.html

${ }^{27} I d$. The Alabama situation, however, is a bit hard to evaluate from a distance. SB 363 apparently failed to come out of committee in March 2018. https://legiscan.com/AL/text/SB363/id/1753340

${ }^{28}$ See e.g. T. C. A. § 50-8-102; F.S.A. § 451.02 (1). Interestingly, most of the laws exempt package delivery and government employers.

${ }^{29}$ See the website of the National Domestic Workers Alliance, https://www.ndwalabs.org/legislation

${ }^{30}$ As an aside, these arguments bear a resemblance to those that have arisen under the infamous Section 230 of the Communications Decency Act of 1996: "No provider or user of an interactive computer service shall be treated as the publisher or speaker of any information provided by another information content provider." As Jeff Kosseff, author of the book "The 26 Words That Created the Internet," has put it, https://www.marketplace.org/shows/marketplacetech/the-law-that-built-the-internet-economy-is-going-international/:

One thing that is interesting about the law, especially as we talk about it as this liability shield, is that it's all-powerful and lets companies ignore everything that's happening on their platforms. It also doesn't require platforms to be hands off. They won't be treated as publishers or take on more liability if they decide to intervene or take things down because it's offensive or it's misinformation.

Here, the same liability shield is evident; it is the identity of the companies as tech companies that is in question, so this is an interesting case of bootstrapping.

${ }^{31}$ T. C. A. $§ 50-8-102$

${ }^{32}$ See above at note 2.

${ }^{33}$ See Restatement Second of Agency, Section 220(2)(b)(whether or not the one employed is engaged in a distinct occupation or business). 
${ }^{34}$ See Restatement Second of Agency, Section 220(2)(e)(whether the employer or the workman supplies the instrumentalities, tools, and the place of work for the person doing the work); Section 220(2)(f)( the length of time for which the person is employed);

${ }^{35}$ T. C. A. $\S 50-8-101(1)$

${ }^{36}$ T. C. A. $\S 50-8-101(2)$

${ }^{37}$ Gobeille v. Liberty Mutual Ins. Co., 136 S.Ct. 936, 944 (2016) (internal citations omitted)

${ }^{38}$ Camargo's Case, 479 Mass. 492 (2018)

${ }^{39}$ It is interesting to note that even online tabulators do not seem able to keep up with the schemata. See Employee or Contractor? The Complete List of Worker Classification Tests By State, https://www.wrapbook.com/workerclassification-tests-by-state/ (seeming not to be aware of the marketplace platform developments). 